\title{
Márta Grabócz (éd.), Les grands topoï du XIX siècle et la musique de Franz Liszt
}

\author{
(Paris : Éditions Hermann, 2018. ISBN 9782705693 541; 432 pp.) \\ Collection du GREAM (Groupe de Recherches Expérimentales sur l'Acte Musical) \\ Sémiotique \& Narratologie
}

Éditions Hermann released in January 2018 a volume edited by Márta Grabócz entitled Les grands topoï du XIX ${ }^{\mathrm{e}}$ siècle et la musique de Franz. Liszt. Most of the papers it contains were delivered at a 2011 conference in Strasbourg to mark the bicentenary of Liszt's birth. My summary of the papers in the volume is intended to give an overview of its diverse themes and approaches.

Grabócz's introduction points out that research into the topoi or "commonplaces" of music was started in the 1980 s by Leonard Ratner. He called musicologists' attention to the benefits of investigating such topoi as dance, religion, military matters or hunting in eighteenth-century music, for example, and how these can help to delineate the narrative aspect of musical forms. With nineteenth-century music, discussion of topoi can be extended to the sublime and negative sublime, to nature, femininity and the exotic, and to topic figures such as Faust and Mephistopheles. It is clearly expedient in Liszt's case to build on literary research into such topoi, which gained importance in the Romantic period.

The book divides into five main chapters. The first, "Entre littérature, beauxarts et mal du siècle" (Between literature, fine arts and nineteenth-century spleen) starts with a paper by Béatrice Didier, a literary historian and Professor Emeritus of the École normale supérieure (Ulm): "Liszt et le sublime négatif de Senancour" (Liszt and the negative sublime of Senancour). She poses a major question of correlation among the arts. How can Liszt's interest in Senancour's Obermann and the negative sublime be transferred to his music when any close translation from literature to music is deemed impossible? Didier suggests some ways to do so, for instance by having the second version of Vallée d'Obermann more strongly monothematic, as a reference to the obsessive monotony of the hero, or by representing the negative sublime by silence, absence of sound (an interruptive rest). It is also possible to read the piece in broader terms, with Liszt identifying himself with Obermann, or more exactly, having the D-sharp in measure 25 followed by 
silence, as a question without answer: absence, where the sublime of Obermann's metaphysical reflection resides.

Márta Grabócz, in a rich, instructive paper, ${ }^{1}$ describes the young Liszt being influenced by the literary tendencies of the early nineteenth century. Relying on the research of literary historians Albert Thibaudet and Paul Bénichou, she identifies the three main groups as 1) anti-revolutionary, émigré, royalist, and Catholic literature (Chateaubriand, also citations of Byron and Schiller) with the key theme of the mal du siècle, 2) the unique case of Senancour, anti-revolutionary and émigré, with the same key themes augmented by the negative sublime, and 3) the religious literature beginning in the 1820s and the humanitarian romanticism of Lamennais and Lamartine working and hoping for a new Christian society. Grabócz states that Liszt not only refers to the literary works of these writers by title, but alludes to the characteristic subject-matter of the first group - the passion of Christ - with doleful instrumental recitatives in several of his piano pieces. Grabócz sees Liszt expressing mal du siècle and the negative sublime in music that lacks tonality and meter. She explains the effect of the third group of literary influences through structural and topical analysis of several works (Vallée d'Obermann, Pensée des morts, Saint François de Paule marchant sur les flots, Dante Sonata, Sonata in B minor, etc.), demonstrating their expressive strategy with a canonical sequence of the four topics spleen, pastoral-amoroso, tempestuoso, and religioso.

Mara Lacchè of the Conservatory S. Giacomantonio, Cosenza deals with the topic figure of Faust especially in terms of his quest for perfect knowledge. Liszt seeks a musical language that can express the omnipresent poetic better than any art can. He writes to Agnes Street-Klindworth about freer development of music aligned to literature. Lacchè offers a detailed semiotic analysis of the three movements of the Faust Symphony, where he sees Faust's mythical figure as symbolizing a universal contradiction between satanic knowledge and redemptive love.

François-Gildas Tual's intriguing paper on Die Loreley gives an overview of the variants of the tale and figure. He writes in detail on Heine's poem and on three settings by Liszt, Clara Schumann, and Johanna Kinkel, comparing the course taken by each composer, with emphasis on narrative approach and complexity of musical form.

François Decarsin, professor at the University of Provence, passed away before the present volume appeared. He suggests that mal de l'avenir (future sickness, a term Liszt used in 1833) depicts a problem comparable to Schoenberg's: how to invent something new after Beethoven. Analyzing Fantaisie romantique sur deux mélodies suisses, he points to the harmonic explorations and force of thematic thought that had lasting effects on Liszt's works. 
Two papers in the chapter deal with works of Liszt inspired by fine art. Siglind Bruhn of the University of Michigan pursues the many intermediary responses to Michelangelo's sculpture Il Penseroso: Milton's pastoral poems, which inspired Handel's musical ode, William Blake's drawings, and Thomas Cole's oils for Liszt's 1839 piano piece, along with the Rodin sculpture that inspired Gabriela Mistral's sonnet and Iris Szeghy's piece for violin and piano.

Laurence Le Diagon-Jacquin analyzes the relation between Wilhelm Kaulbach's painting Die Hunnenschlacht and Liszt's symphonic poem of the same title. She notes that the musical elements correspond in number to the visual ones, yet cannot be matched in each case. She shows that the sonata form used by Liszt, though apt in expressing the battle between Huns and Christians, is altered by introducing as a resolution the theme of the Cross (the Crux fidelis at the center of Liszt's concept).

The second chapter of the volume - "Nouvelle esthétique, nouvelles formes au XIX ${ }^{\mathrm{e}}$ siècle" (New aesthetics, new forms of the nineteenth century) - starts with a broad, intriguing paper by Constantin Floros, Professor Emeritus of Hamburg University. He first runs over the nineteenth-century semanticization of music. References to literature (largely epic and lyrical works with philosophical themes) are especially notable in Liszt. To semanticize his music, Liszt uses a vocabulary of featured motifs reflecting his spiritual world. At the center of the Weimar period, Floros states, stood the polar opposites of divine and evil, portrayed in Liszt by the Cross motif and the tritone.

Albert Van Der Schoot contributes a dissertation on the history of golden section that matches the title of the second chapter perfectly. He looks at whether Liszt could have used a golden section as a tool in his works. Could he integrate it into his vocabulary, to assist in semanticizing his music as seen with the Cross motif and the tritone? We learn from a letter from Liszt to Marie zu Sayn-Wittgenstein that he was interested in the golden section and in Adolf Zeising's Neue Lehre von den Proportionen des menschlichen Körpers (1854). But as Van Der Schoot shows, he is unlikely to have read the book and even if he had, could not have made much use of it in his works, as Zeising's musical competence was modest.

The paper by Claudia Colombati, Professor of aesthetics and philosophy of music at the Tor Vergata University of Rome, reviews the sources of Liszt's creative inspiration, notably the heroic sublime. She also analyses the impact of such topoi as nature, wandering, major European myths (e.g. Orpheus, Prometheus) and literature (Faust, Hamlet).

The papers by Jean-Paul Olive, Professor at the University of Paris 8, and Bruno Moysan, Professor at Paris Institute of Political Studies, cover the questions of musical form referred to in the chapter title. The former, surprisingly but convincingly, compares the compositional approaches of Liszt and Schoenberg. Olive analyzes Liszt's Sonata in B minor and Schoenberg's Chamber Symphony side by side and describes the features they share: four movements integrated into 
one complex form and hierarchic thematic material that is diverse, yet organic enough to give coherence of form. He touches on the isotopes and characters conveyed by the themes in the pieces and the effort at expressiveness in Liszt's and in Schoenberg's music.

Bruno Moysan's analysis of several works from Liszt's Weimar period is stunning as well. He first compares the solita forma - a four-part operatic form with increasing tempi, used by Rossini and other Italian opera composers - with Liszt's Grande fantaisie sur La Clochette de Paganini and Réminiscences de Don Juan as examples, and identifies their similarities. He goes on to suggest that the experience Liszt gained with these large-scale, mostly operatic fantasies may have influenced his later works as well. Following on from the four-part solita forma, Moysan establishes four types of a so-called four-part scheme, applying it as examples to Liszt's First and Second Concertos, Totentanz, Dante Sonata, Tasso, Prometheus, Sonata in B minor, Die Ideale, Les Préludes, and Faust Symphony.

The third main chapter, "Présence de la femme et de l'amour dans la musique de Liszt" (The presence of the woman and of love in Liszt's music), contains four studies, two of them linked more strictly to the topos of femininity. Grégoire Caux, who teaches at the University Paris IV-Sorbonne, examines in fine detail in his paper "Les modes de présence de la figure féminine chez le dernier Liszt" (Modes of presence of the feminine figure in Franz Liszt's work) how pieces can be linked to the topos. On a quite basic level, he remarks, pieces can be linked to femininity by a title that refers to a figure like Saint Dorothy or Gretchen or by dedication to a lady, although in the second case no musical signs of feminine character may appear. Pieces in the first group may display musical particularities, a "typology" as Caux calls it, such as use of diatonic, mostly major or modal keys, prominence of intervals of a third, piano dynamics, arpeggios, and retarded harmonic movement. These signs of the feminine topos can also be found in pieces without femininity in their title, such as the Impromptu of 1872 or the Jeux d'eau à la Villa d'Este. Caux notes that several late pieces evoke memories of the past: the Valses oubliées, Romances oubliées, the first Élégie, the Ehemals in Weihnachtsbaum, and many religious pieces all share such femininities as well. Caux sees the feminine in these not as an independent topos, but as part of the topoi of past and religion.

Yusuke Nakahara, contributor of the essay "Gretchen, Zerlina and Leonore. Variations on Gretchen for the Faust Symphony" is a researcher at the Bartók Archives in Budapest. He gives a profound analysis of four themes representing the feminine figure of Gretchen in different ways. Nakahara turns first to the first theme in the second movement of the Faust Symphony, drawing the attention to its rhythmic ambiguity, depicting the girl as "a hesitant or confused woman." He next analyzes the song Es war ein König in Thule (1842), sung by Gretchen after meeting Faust. The theme resembles the final form of the Gretchen theme of Liszt's symphony, suggesting he borrowed that from his Lied, and it also shows the young 
woman in a very dramatic way, which may explain the rhythmic ambiguity of the theme. Also examined are two sketches (D-WRgs 60/N4). The earlier emphasizes Gretchen's simplicity, referring musically to the pastoral-like aria "Batti, batti o bel Masetto" in Gavotte rhythm from Don Giovanni, sung by the lower-class woman Zerlina. The second refers melodically and harmonically (with a II-IV succession) to a trio in Act 2 of Fidelio, illustrating her as an object-cum-subject of redemption. The final form of the theme seems to owe something to all these images of Gretchen.

Megan McCarty of Boston University has contributed a remarkable paper in English on "Franz Liszt's Settings of Poems by Victor Hugo: A Previously Unrecognized Song Cycle." She compares the first (1844) and second (1860) version of the set, describing the musical and sequential changes, and the overall transformation of a collection to a narrative cycle that tells about love.

The fourth essay, "Les différentes notions d'amour dans les lieder de Franz Liszt" (Different notions of love in Liszt's Lieder) is likewise about Liszt's love songs. Małgorzata Gamrat of the University of Warsaw analyzes Liszt songs on the three sonnets by Petrarch, and also three Lieder on German texts (Hohe Liebe, Gestorben war ich, and $O$ lieb' so lang $d u$ lieben kannst!). Gamrat's elusive hypothesis that the two series form a "megacycle" based on shared musical features seems not to convince even the author herself. Although detailed description of text and music such as is found here reveals much about the pieces, the question arises whether it would be more meaningful to use analysis as a tool for corroborating a well-defined train of thought or supportable assumption.

The chapter "Nature et horizons lisztiens" (Nature and horizons in the world of Liszt) starts with a surprising paper by Bertrand Ott that opens wide horizons by introducing air and space as a fundamental topic in Liszt's music. Founding his thoughts on Gaston Bachelard's writings, he says air as space for movement and different types of winds, i.e. air in motion, all appear in Liszt's work, and gives fascinating and largely convincing examples. Michael Eisenberg of McGill University uses Liszt's Vallée d'Obermann to reveal how the topoi of nature and sublime are expressed musically. The third paper, by Sandra Myers, takes a special case of exotic topoi: the Spanish contrabandista. The essay concerns Liszt's Rondeau Fantastique sur un thème Espagnol based on a polo (Andalusian song and dance) by Manuel García. His song introduces a smuggler whose topic figure personifies bravery, loyalty, mystery, and struggle for freedom. The song inspired Liszt to write a rondo that in turn inspired George Sand to write an article on Liszt's piece and the figure of the contrabandista.

The fifth chapter, "Liszt et le piano romantique" (Liszt and the Romantic piano), draws attention to the role of instruments and interpretation. The pianist and expert on romantic pianos Olivia Sham, in her study "Changing Pianos, Changing Language: An Investigation into Liszt's Harmonies poétiques et religieuses," sees the changes in the instrument during the nineteenth century - especially its 
increasing volume - modifying how mounting tension and culmination are composed. She also explains what these technical features have to do with the topoi and how important they are in the interpreting the young Liszt's piano music. Sham affirms that on earlier pianos of the 1840s Liszt could achieve the psychological effect of culmination only by "frantically switching between various topics associated with storminess" (p. 323).

Daniela Tsekova's "Les interprètes face à la Sonate en si mineur de Franz Liszt" (Performers facing Franz Liszt's Sonata in B minor) gives a detailed performance analysis of ten pianists of the Russian and American schools. It compares volumes, tempi, agogics and other sides of the two main themes and some culminations in the Sonata, and is certain to be highly instructive for pianists as well as scholars, even if it might have been more effective as a lecture, with illustrations from the recordings analyzed.

A third paper connected more strictly to the chapter title is Nathalie Hérold's "Timbre et signification musicale" (Timbre and musical signification) offering neat analysis of the piano's timbre with regard to its topic meaning and its role in the understanding of musical forms.

In an essay on Liszt's piano piece Invocation, Panu Heimonen of the University of Helsinki draws on Eero Tarasti's concepts in his book Existential Semiotics (2000) in analyzing the work. I believe that with keen interest one might profit from this complex description and reading, but a simpler and clearer scholarly language would be more help to those willing to learn from it than throwing difficulties in the way of the readers' understanding.

Kasimir Morski, a Polish pianist and conductor, has written on aspects of creative thought in the Sonata in B minor and the Concerto in E-flat Major. Unfortunately, little new is learned about the pieces, especially as the text is rather confusingly obscure.

Tibor Szász, pianist and piano professor of the Hochschule für Musik in Freiburg, contributes an exciting survey of a transcription by Liszt of the song Es hat geflammt by Maria Pavlovna. This marks the first publication of the piece with Liszt's own prelude and postlude. Szász presents pervasive observation of the use of the scale degrees 6, 5, 1 in the prelude, and in the B-minor Sonata and Faust Symphony, stating that this scale gives the "basic tonal pillars of the opening themes" of the latter pieces. Like Dorothea Redepenning, ${ }^{2}$ he also hypothesizes that the thirteen-note theme (he explains why thirteen) at the beginning of the Faust Symphony may derive from Schubert's Szene aus Goethes Faust, D. 126b, and from the Macrocosm symbol mentioned in the opening of Goethe's Faust.

The volume's overall design and editing is of a high standard; alongside blackand-white figures, it contains 16 color illustrations of good quality. In most of 
the cases it was illuminating to read the essays, whether they investigated Liszt's œuvre from an aesthetic, a formal or a technical point of view. The focus on topoi or commonplaces provides a fresh look at works already analyzed by many scholars, while raising and possibly responding to new issues in Liszt's music and thoughts.

Júlia Fedoszov 
